Research article

\title{
MOLECULAR DETECTION OF PCV2 AND PPV IN PIGS IN REPUBLIC OF SRPSKA, BOSNIA AND HERZEGOVINA
}

\author{
LUKAČ Bojan ${ }^{1 *}$, KNEŽEVIĆ Aleksandra ${ }^{3}$, MILIĆ Nenad ${ }^{2}$, KRNJAIĆ Dejan ${ }^{2}$, \\ VELJOVIĆ Ljubiša ${ }^{4}$, MILIĆEVIĆ Vesna ${ }^{4}$, ZORIĆ Andrea ${ }^{2}$, ĐURIĆ Spomenka ${ }^{5}$, \\ STANOJEVIĆ Maja ${ }^{3}$, NIŠAVIĆ Jakov ${ }^{2}$
}

${ }^{1} \mathrm{PhD}$ student; ${ }^{2}$ Department of Microbiology, Faculty of Veterinary Medicine University of Belgrade, Bul. Oslobođenja 18, Belgrade, Serbia; ${ }^{3}$ Virology Department, Institute of Microbiology and Immunology, School of Medicine, University of Belgrade, Dr Subotića 8, Belgrade, Serbia; ${ }^{4}$ Scientific Veterinary Institute of Serbia, Vojvode Toze 14, Belgrade, Serbia; ${ }^{5}$ Department of Economics and Statistics Faculty of Veterinary Medicine University of Belgrade, Bul. Oslobođenja 18, Belgrade, Serbia

(Received 10 September; Accepted 28 December 2015)

The presence of porcine circovirus 2 and porcine parvovirus was examined in forty clinical samples of spleen, lymph nodes and lungs originating from non-vaccinated swine by polymerase chain reaction. All animals were reared in extensive livestock farming systems in different geographical districts of Republic of Srpska, Bosnia and Herzegovina. Porcine circovirus 2 DNA was detected in four lymph node and two spleen samples (15\%), while porcine parvovirus DNA was identified in five lymph node samples $(12.5 \%)$. The presence of both viruses was detected in three lymph node samples (7.5\%). Partial nucleotide sequence of ORF1 gene of 2 porcine circovirus 2 and VP2 gene of 2 porcine parvovirus isolates was determined. The nucleotide sequences of two PCV2 isolates from RS-BIH included in phylogenetic typing are similar and cluster together with the strain Mantova isolated from domestic pigs in Italy, strains DE006-14 and DE222-13 isolated from pigs in Germany as well as with the strain Jvnan isolated from pigs in China. Also, analyzed PCV2 isolates were partially similar to the strain NIV-C SRB isolated from pigs in Serbia. The nucleotide sequences of two PPV isolates that were included in phylogenetic typing showed a high level of similarity with the strain Challenge isolated from pigs in UK, strain Kresse isolated from pigs in USA and strains 77 and LZ isolated from pigs in China.

Key words: porcine circovirus 2, porcine parvovirus, nucleotide sequence, Republic of Srpska, Bosnia and Herzegovina

\section{INTRODUCTION}

Porcine circovirus type 2 (PCV2) is a non-enveloped, single-stranded, circular DNA virus of the genus Circovirus, family Circoviridae. Three open reading frames (ORFs

\footnotetext{
*Corresponding author: e-mail: bojan.lukac@gmail.com
} 
- ORF1, ORF2 and ORF3) were recognized in the PCV2 genome [1]. PCV2 is recognized as a necessary, but not sufficient, agent of porcine-circovirus-associated diseases (PCVAD), including postweaning multisystemic wasting syndrome (PMWS) and porcine dermatitis and nephropathy syndrome (PDNS) [2]. Other pathological conditions linked to PCV2 are reproductive failure, proliferative and necrotizing pneumonia and respiratory disease [3]. PCV2 usually affects animals between 5 and 16 weeks of age [4]. The more severe clinical symptoms are present when pigs are co -infected with more than one virus in comparison with infection caused by a single virus. The standard laboratory methods for diagnosis of diseases caused by PCV2 are mainly based on immunohistochemistry and in situ hybridization directly in tissue samples or by real-time quantitative polymerase chain reaction [5,6]. Also the conventional polymerase chain reaction is often used as a standard method for detection of PCV2 in clinical samples [7-9].

Porcine parvovirus (PPV) belongs to the genus Parvovirus, subfamily Parvovirinae, family Parvoviridae and is among the major etiological agenst of reproductive failure in sows such as fetal death, mummification, stillbirth and delayed return to estrus [10]. The manifestation of clinical disease depends on the pathogenicity of the virus and on the stage of gestation [11]. PPV is a small, non-enveloped, single-stranded negative-sense DNA virus. The genome contains two major ORFs (ORF1 and ORF2) which encode non-structural (NS1, NS2 and NS3) and structural proteins (VP1, VP2 and VP3). Although the VP1/VP2 genes are highly conserved, PPV strains can be distinguished by their different pathogenicity [8]. Virus isolation in cell cultures is laborious and time consuming, and it cannot be achieved for all PPV strains. Other diagnostic techniques, such as conventional PCR or real - time PCR are widely used [12]. Different studies showed that PCR is very sensitive method for PPV detection [13].

\section{MATERIAL AND METHODS}

\section{Samples}

Forty samples (spleen, lymph nodes and lungs) were collected after slaughtering, from non-vaccinated clinical healthy swine (gilts and sows) and from animals with certain reproductive and respiratory problems. All animals were reared in extensive livestock farming systems in different geographical districts of Republic of Srpska, Bosnia and Herzegovina.

\section{Viruses}

The viruses used as positive controls in the reactions were: PCV2 strain 1010-Stoon (provided by Scientific Veterinary Institute "Novi Sad", Novi Sad, Serbia) used as the positive control in PCR; and PPV strain Teen (American Bioresearch, USA) used as the positive control for virus isolation in cell culture and polymerase chain reaction (PCR). 


\section{Virus isolation}

For isolation of PPV, cell lines PK-15 and SK-6 were used (IZSBS, Brescia). Clinical samples (spleen tissue, lymph nodes and lungs) were individually inoculated in 24-well microtiter plates with monolayer of PK-15 and SK-6 cell lines. Clinical samples were previously prepared for inoculation in cell culture by standard procedure for virus isolation [14]. Each plate was inoculated with $100 \mu$ l of $10 \%$ suspension of samples in PBS and incubated for $1 \mathrm{~h}$ at $37^{\circ} \mathrm{C}$ in an environment with $5 \% \mathrm{CO}_{2}$. After one hour, $500 \mu \mathrm{l}$ of minimum essential medium (MEM, Biochrom, Germany) with $2 \%$ fetal calf serum (PAA, Austria) was added. Plates were then incubated in the above mentioned conditions and observed every day for the appearance of cytopathic effect of virus (CPE) for PPV. The identification of isolated strains of PPV was performed by haemagglutination inhibition (HI test) test after the CPE appearance or after three consecutive blind passages [15].

\section{PCR detection}

The extraction of viral DNA from tissue samples was performed using Thermo Scientific GeneJet Genomic DNA Purification Kit (Thermo Scientific, USA) according to the manufacturer's instructions. For PCR amplification of the specific part of PCV2 genome that encodes ORF1 protein the folowing primers were used (forward 5-CAGCAACATGCCCAGCAAGAAGAAT-3 and reverse 5-TCG ATCACACAGTCTCAGTAG-3) [13]. For PCR detection of PPV, primers for the part of PPV genome that encodes VP2 protein were used (forward 5-CACAGAAGCAACAGCAATTAGG-3 and reverse 5-CTAGCTCTTGTGAAGATGTGG-3) [13]. The PCR was done by Dream Taq PCR Master Mix (Thermo Scientific, USA) according to the manufacturer's instructions.

PCR protocol for the detection of PCV2 DNA comprised of primary denaturation at $95^{\circ} \mathrm{C}$ for 4 minutes, 40 repeated cycles of denaturation at $95^{\circ} \mathrm{C}$ for $30 \mathrm{sec}$., annealing at $56^{\circ} \mathrm{C}$ for $30 \mathrm{sec}$. and $72^{\circ} \mathrm{C}$ for 1 minute. The process was finalised with a final elongation at $72^{\circ} \mathrm{C}$ for 10 minutes. The presence of specific $703 \mathrm{bp}$ band detected by agarose gel electrophoresis was considered as a positive result of PCV2 presence [13].

PCR protocol for the detection of PPV DNA consisted of primary denaturation at $95^{\circ} \mathrm{C}$ for 4 minutes, 36 repeated cycles of denaturation at $95^{\circ} \mathrm{C}$ for 30 sec., annealing at $55^{\circ} \mathrm{C}$ for $30 \mathrm{sec}$. and $72^{\circ} \mathrm{C}$ for 1 minute. The process was finalised with a final elongation at $72{ }^{\circ} \mathrm{C}$ for 10 minutes. The presence of specific $203 \mathrm{bp}$ band detected by agarose gel electrophoresis was considered as a PPV positive result [13].

\section{PCV 2 and PPV direct sequencing}

PCR products were purified with QIA quick Purification Kit (Qiagen, Valencia, CA, USA). The purified PCR products were subsequently sequenced with Big Dye Terminator Cycle Sequencing Kit (PE Applied Biosystems, Foster City, CA, USA) using PCR primers as sequencing primers. 
Direct sequencing of PCV2 and PPV sequences was performed by Sanger sequencing method. Cycle sequencing protocol comprised of an initial denaturation at $96{ }^{\circ} \mathrm{C}$ for 2 minutes, followed by 40 repeated cycles of denaturation at $96{ }^{\circ} \mathrm{C}$ for $10 \mathrm{sec}$, annealing at $50{ }^{\circ} \mathrm{C}$ for $5 \mathrm{sec}$ and elongation at $60^{\circ} \mathrm{C}$ for 4 minutes. The products were purified by isopropanol and denatured at $95^{\circ} \mathrm{C}$ for 2 minutes. Sequencing reactions were analyzed on the ABI Prism 310 Genetic Analyzer. The obtained nucleotide sequences were aligned and compared with virus sequences available in the Gene Bank database using BLAST tool (http://www.ncbi.nlm.nih.gov/BLAST). Evolutionary analyses were conducted with MEGA 6 software. The phylogenetic tree for PCV2 and for PPV viral strains were constructed using Neighbor Joining algorithm with 1000 bootstrap replicates. The evolutionary distance computed using Maximum Composite Likelihood method.

\section{RESULTS}

\section{PCR}

Forty samples (spleen, lymph nodes and lungs) were individually examined by PCR method for the presence of PCV2. In total, 6 out of 40 samples, four lymph node samples and two spleen samples were found positive (15\%) (Fig. 1).

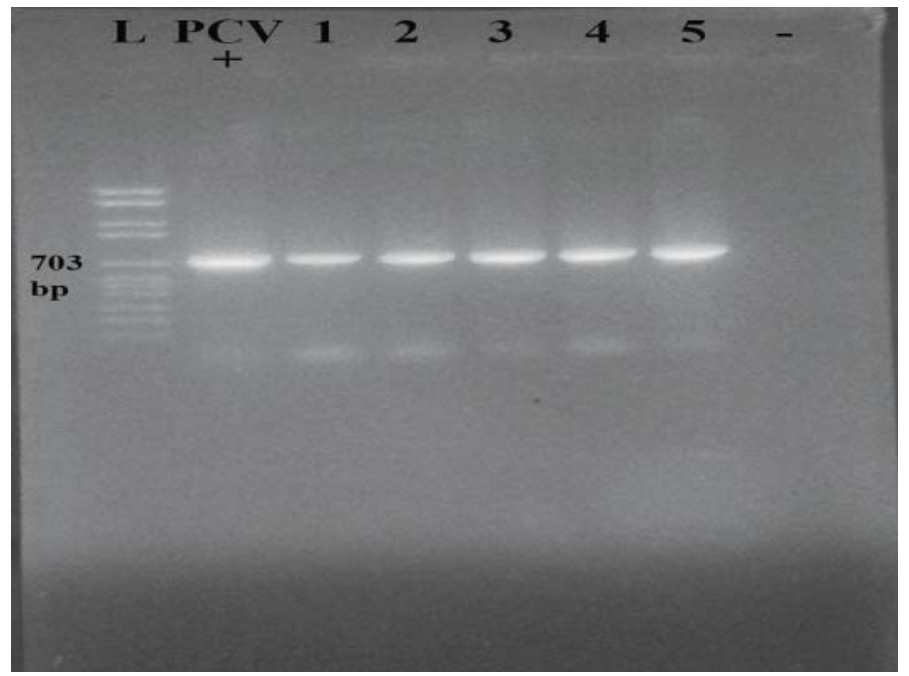

Figure 1. PCR detection of PCV2

Gel electrophoresis of PCV2 PCR products (Line L - DNA Ladder; Line PCV2+ - positive control PCV2 strain 1010 - Stoon; Samples 1-5; Line „,-, - negative control)

The same samples were examined for the presence of PPV. A total of five lymph node samples were positive for the presence of viral DNA (12.5\%) (Fig. 2). Three lymph node samples were positive for both PPV and PCV2 genome sequences (7.5\%). 


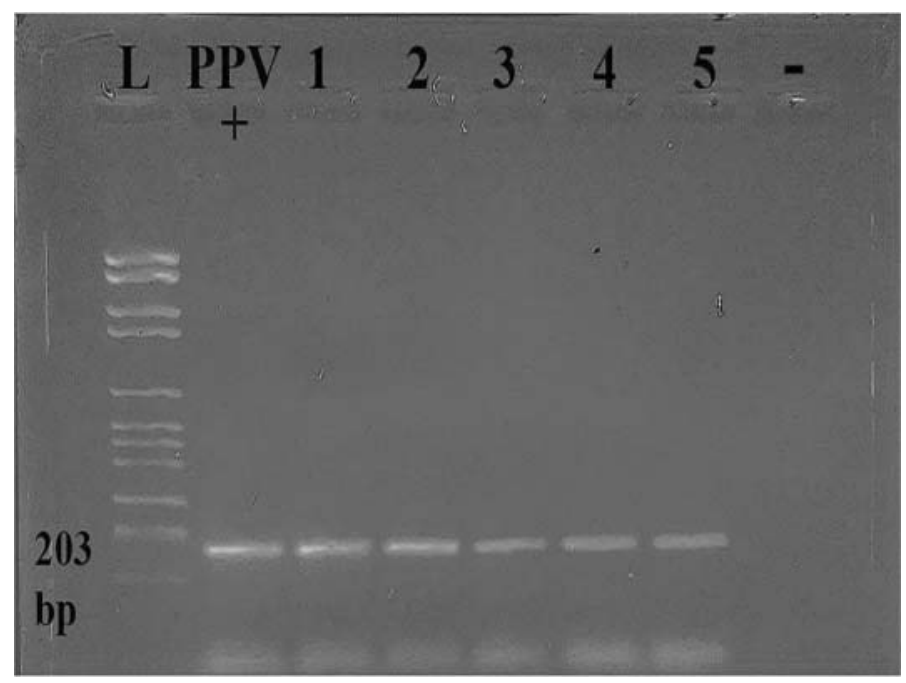

Figure 2. PCR detection of PPV

Gel electrophoresis of PPV PCR products (Line L - DNA Ladder; Line PPV+ - positive control PPV strain Teen; Samples 1-5; Line "-" - negative control)

\section{Isolation of viruses in cell lines}

The samples were inoculated into two different cell lines PK-15 and SK-6. The presence of PPV isolates in inoculated cell lines was not observed.

\section{PCV2 and PPV nucleotide sequences}

The nucleotide sequences of two PCV2 isolates from RS-BIH included in phylogenetic typing are similar and cluster together with strain Mantova isolated from domestic pigs in Italy, strains DE006-14 and DE222-13 isolated from pigs in Germany as well as with the strain Jvnan isolated from pigs in China. Also, analyzed PCV2 isolates were partially similar with the strain NIV-C SRB isolated from pigs in Serbia (Fig. 3). The nucleotide sequences of two PPV isolates that were included in phylogenetic typing showed a high level of similarity with the strain Challenge isolated from pigs in UK, strain Kresse isolated from pigs in USA and strains 77 and LZ isolated from pigs in China. However, US strain NADL2 and VRI-1 strain isolated in South Korea branched separately in the phylogenetic tree indicating a higher level of difference on analyzed nucleotide sequence level between those strains and PPV isolates obtained in our study (Fig. 4). 


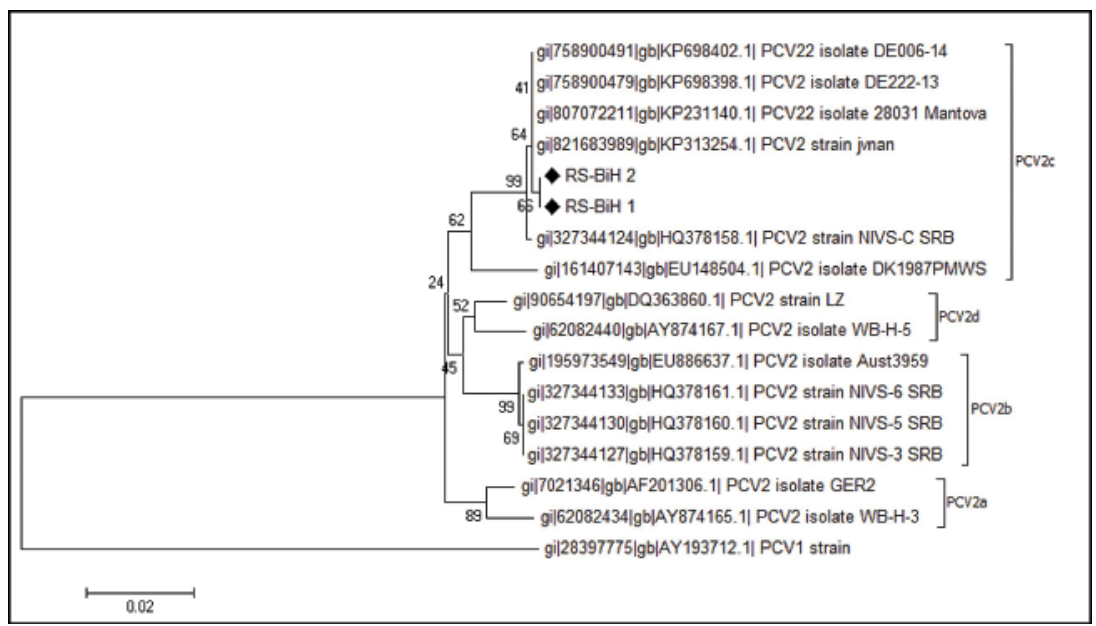

Figure 3. Evolutionary relationships of PCV2 .

Evolutionary analyses were conducted with MEGA 6 software. The tree was constructed using Neighbor Joining algorithm with 1000 bootstrap replicates. The evolutionary distances were computed using Maximum Composite Likelihood method.

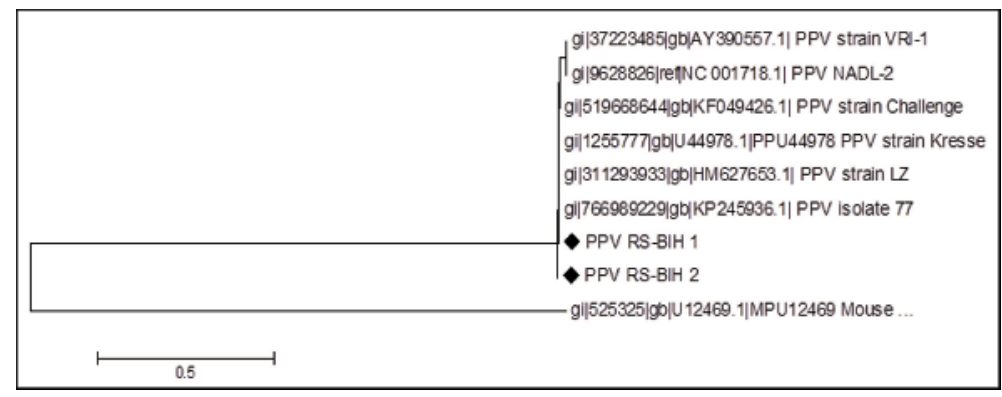

Figure 4. Evolutionary relationships of PPV .

Evolutionary analyses were conducted with MEGA 6 software. The tree was constructed using Neighbor Joining algorithm with 1000 bootstrap replicates. The evolutionary distances were computed using Maximum Composite Likelihood method.

\section{DISCUSSION}

Molecular methods are very useful tools for detection of different viruses in clinical samples. In the neighbouring country Serbia besides immunohistochemistry, PCR was successfully used for the detection and later on for molecular characterization of circulating PCV2 strains [8,9]. Ogawa et al. [13] examined 33 principal organs collected from PRDC/PMWS-suspected pigs and 26 organs of aborted foetuses by multiplex PCR for the presence of PCV2 and PPV. The results of this study confirmed 32 PCV2 positive samples (96.9\%) and 9 samples positive for PPV (27.3\%). Nine PPV positive samples $(27.3 \%)$ were co-infected with PCV2. Savić et al. [16] detected PCV2/PRRSV co-infection in 59 of 235 samples of swine from ten farms. In our examination, $15 \%$ of examined samples were positive for PCV2 and $12.5 \%$ were positive for PPV, 
while $7.5 \%$ of samples were co-infected with PCV2 and PPV, but our samples were collected from animals without or with nonspecific clinical symptoms. This is in correlation with previous reports of subclinical infection of swine caused by PCV2 [3] and PPV [12]. Our study, as well as findings from previously mentioned studies, showed that PCR method can be used for fast, precise and accurate identification of the aforementioned viruses without isolation in cell line. Soares et al. [17] used PCR for the detection of PPV using primers for highly conserved nonstructural protein gene, NS-1. A total of 24 clinical samples which were sent for PPV isolation were also tested by HA, PCR and nested-PCR. Of those, nine were positive using isolation in cell cultures and 18 were positive using both PCR and nested-PCR. In all samples in which PPV had been isolated, the virus genome was successfully detected by PCR. Five samples which were negative in PCR were positive by nested-PCR. This finding is supported in our study where $12.5 \%$ of samples were positive for PPV by PCR, but were not isolated on cell culture in virus isolation. Henriques et al. [18] analysed the nucleotide sequence of ORF1 gene of PCV2. All 22 PCV2 strains were obtained from domestic pigs originating from different regions of Portugal. The nucleotide similarity observed among 22 strains varied between $96 \%$ and $100 \%$. The majority of the strains branched in genotype PCV2b, while six strains with a common geographical origin obtained between 2007 and 2009, were included in genotype PCV2a. Ramos et al. [19] analyzed PCV2 strains from Uruguay. The molecular analysis of the PCV2 cap gene showed a nucleotide similarity of $99.7 \%$ among Uruguayan isolates and with two of the Brazilian isolates included in this study. Uruguayan isolates shared a nucleotide and amino acid identity of $99.1-99.5 \%$ with Argentinean strains, which were in turn more closely related to isolates from France, Cuba, Canada and USA. Phylogenetic analysis revealed that Uruguayan PCV2 strains belongs to PCV2a genotype. The nucleotide sequences of two PCV2 isolates from our study included in phylogenetic typing are highly similar and cluster together with strain Mantova isolated from domestic pigs in Italy, strains DE006-14 and DE222-13 isolated from pigs in Germany, as well as with the strain Jvnan isolated from pigs in China. Also, analyzed PCV isolates were partially similar with the strain NIVS-C SRB isolated from pigs in Serbia. Our results are in correlation with the findings of Chae et al. [20] obtained during molecular analysis of 21 full genome PCV2 sequences. They found variability within ORF2 gene (91.1 - 99.7\% identity among PCV2 strains), while ORF1 gene was highly conserved (96.5100\%). Phylogenetic analysis revealed that all Korean PCV2 strains belong to PCV2a and PCV2b genotype. Xu et al. [21] compared the nucleotide sequence of the VP2 gene of the PPV NE/09 strain and other PPV strains in China. The results showed that the VP2 gene of the PPV-NE/09 strain had high sequence similarity with other PPV isolates. The results showed that according to the phylogenetic relationship of the VP2 gene of PPV-NE/09, the isolate was a new mutant strain of PPV prevailing in China. The phylogenetic analysis showed a high level of similarity between nucleotide sequences of PPV isolates obtained in our study and sequences of strain Challenge isolated from pigs in UK, strain Kresse isolated from domestic pigs in USA, and strains 77 and LZ isolated from pigs in China. However, US strain NADL2 and VRI-1 
strain isolated in South Korea branched separately in the phylogenetic tree indicating higher level of difference on analyzed nucleotide sequence level between those strains and PPV isolates obtained in our study.

Of note, to the best of our knowledge, the presented data represents the first report of the presence and molecular characterization of PCV2 and PPV in swine in Republic of Srpska, Bosnia and Herzegovina.

\section{Acknowledgments}

This study was supported by the Ministry of Education, Science and Technological Development of the Republic of Serbia (Grant no. 31008 and 173024).

\section{Authors' contributions}

LB collection of samples, KA carried out the molecular genetic studies and participated in the sequence alignment, MN participated in the sequence alignment, $\mathrm{KD}$ participated in the sequence alignment, VLJ participated in the design of the study, VM participated in the design of the study, ZA carried out the molecular genetic studies and participated in the sequence alignment, DJS participated in the design of the study, SM carried out the molecular genetic studies and participated in the sequence alignment, NJ participated in the design of the study, carried out the molecular genetic studies, participated in the sequence alignment and drafted the manuscript. All authors read and approved the final manuscript.

\section{Declaration of conflicting interests}

The author(s) declared no potential conflicts of interest with respect to the research, authorship, and/or publication of this article.

\section{REFERENCES}

1. Wei C, Zhang M, Chen Y, Xie J, Huang Z, Zhu W, Xu T, Cao Z, Zhou P, Su S, Zhang G: Genetic evolution and phylogenetic analysis of porcine circovirus type 2 infections in southern China from 2011 to 2012. Infect Genet Evol 2013, 17:87-92.

2. Haley C, Wagner B, Puvanendiran S, Abrahante J, Murtaugh MP: Diagnostic performance measures of ELISA and quantitative PCR tests for porcine circovirus type 2 exposure using Bayesian latent class analysis. Prev Vet Med 2011, 101:79-88.

3. Segales J: Porcine circovirus type 2 (PCV2) infections: Clinical signs, pathology and laboratory diagnosis. Virus Res 2012, 164:10-19.

4. Marks FS, Reck J, Almeida LL, Berger M, Corre AMR, Driemeier D, Barcellos D, Guimara JA, Termignoni C, Canal CW: Porcine circovirus 2 (PCV2) induces a procoagulant state in naturally infected swine and in cultured endothelial cells. Vet Microbiol 2010, 141:22-30. 
5. Chang CY, Deng MC, Wang F, Tsai H, Yang C, Chang C, Huang Y: The application of a duplex reverse transcription real-time PCR for the surveillance of porcine reproductive and respiratory syndrome virus and porcine circovirus type 2. J Virol Methods 2014, 201:13-19.

6. Grau-Rama L, Segales J: Detection of porcine reproductive and respiratory syndrome virus, porcine circovirus type 2, swine influenza virus and Aujeszky's disease virus in cases of porcine proliferative and necrotizing pneumonia (PNP) in Spain. Vet Microbiol 2007, 119:144-151.

7. Liu JK, Wei CH, Zang XY, Dai AL, Li XH: Multiplex PCR for the simultaneous detection of porcine reproductive and respiratory syndrome virus, classical swine fever virus, and porcine circovirus in pigs. Mol Cell Probes 2013, 27:149-152.

8. Toplak I, Lazić S, Lupulović D, Prodanov-Radulović J, Becskei Z, Došen R, Petrović T: Study of the genetic variability of porcine Circovirus type 2 detected in Serbia and Slovenia. Acta Vet Hungarica 2012, 60:409-420.

9. Becskei Z, Aleksić - Kovačević S, Rusvai M, Balka G, Jakab C, Petrović T, Knežević M: Distribution of porcine circovirus 2 Cap antigen in the lymphoid tissue of pigs affected by postweaning multisystemic wasting syndrome. Acta Vet Hungarica 2010, 58:483-498.

10. Cadar D, Dan A, Tombacz K, Lorincz M, Kiss T, Becskei Z, Spinua M, Tuboly T, Csagola A: Phylogeny and evolutionary genetics of porcine parvovirus in wild boars. Infect Genet Evol 2012, 12:1163-1171.

11. Dias AS, Gerber PF, Araujo AS, Auler PA, Gallinari GC, Lobato ZIP: Lack of antibody protection against Porcine circovirus 2 and Porcine parvovirus in naturally infected dams and their offspring. Res Vet Sci 2013, 94:341-345.

12. Chen HY, Li XK, Cui BA, Wei ZY, Li XS, Wang YB, Zhai L, Wang ZY: A TaqMan-based real-time polymerase chain reaction for the detection of porcine parvovirus. J Virol Methods 2009, 156:84-88.

13. Ogawa H, Taira O, Hirai T, Takeuchi H, Nagao A, Ishikawa Y, Tuchiya K, Nunoya T, Ueda S: Multiplex PCR and multiplex RT-PCR for inclusive detection of major swine DNA and RNA viruses in pigs with multiple infections. J Virol Methods 2009, 160:210-214.

14. Nišavić J, Milić N, Knežević A: Laboratorijska dijagnostika virusnih infekcija. In:Izolacija virusa u kulturi ćelija. Beograd, Srbija: Naučna KMD; 2013, 34-36.

15. Nišavić J, Milić N: Examination of the activity of glycoprotein $\mathrm{HN}$ and $\mathrm{F}$ antigens of outer envelope of the parainfluenza virus type 3 by using fusional, hemolytic and hemagglutinating test, in vitro. Acta Vet-Beograd 2006, 56:431-436.

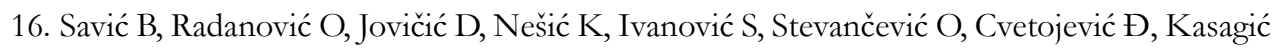
D: Survey of infectious agents associated with porcine respiratory disease complex (PRDC) in Serbian swine herds using polymerase chain reaction (PCR) detection. Acta Vet-Beograd 2015, 65:79-88.

17. Soares RM, Durigon EL, Bersano JG, Richtzenhain LJ: Detection of porcine parvovirus DNA by the polymerase chain reaction assay using primers to the highly conserved nonstructural protein gene, NS-1. J Virol Methods 1999, 78:191-198.

18. Henriques AM, Duarte M, Fagulha T, Ramos F, Barros SC, Luis T, Fevereiro M: Molecular study of porcine circovirus type 2 circulating in Portugal. Infect Genet Evol 2011, 11:21622172.

19. Ramos N, Mirazo S, Castro G, Arbiza J: Molecular analysis of Porcine Circovirus Type 2 strains from Uruguay: Evidence for natural occurring recombination. Infect Genet Evol 2013, 19:23-31. 
20. Chae C: Porcine circovirus 2 and its associated diseases in Korea. Virus Res 2012, 164:107113.

21. Xu YG, Cui LC, Wang HW, Huo GC, Li SL: Characterization of the capsid protein VP2 gene of a virulent strain NE/09 of porcine parvovirus isolated in China. Res Vet Sci 2013, 94:219-224.

\section{MOLEKULARNA DETEKCIJA PCV2 I PPV KOD SVINJA U REPUBLICI SRPSKOJ, BOSNA I HERCEGOVINA}

LUKAČ Bojan, KNEŽEVIĆ Aleksandra, MILIĆ Nenad, KRNJAIĆ Dejan, VELJOVIĆ Ljubiša, MILIĆEVIĆ Vesna, ZORIĆ Andrea, ĐURIĆ Spomenka, STANOJEVIĆ Maja, NIŠAVIĆ Jakov,

Prisustvo svinjskog cirkovirusa 2 i parvovirusa svinja ispitano je u četrdeset uzoraka (slezina, limfni čvorovi, pluća) poreklom od nevakcinisanih svinja primenom lančane reakcije polimeraze. Sve životinje su bile iz ekstenzivnog načina gajenja i iz različitih regiona Republike Srpske, BiH. Četiri uzorka limfnih čvorova i dva uzorka slezine su bili pozitivni na prisustvo DNK svinjskog cirkovirusa 2 (15\%), dok je kod pet uzoraka limfnih čvorova utvrđeno prisustvo DNK parvovirusa svinja (12.5\%). U uzorcima poreklom od tri svinje utvrđeno je prisustvo nukleinske kiseline oba prethodno navedena virusa $(7.5 \%)$. Metodom sekvenciranja određena je nukleotidna sekvenca dela ORF1 gena dva izolata svinjskog cirkovirusa 2 i dela VP2 gena dva izolata parvovirusa svinja. Nukleotidne sekvence dva izolata PCV2 utvrdena u uzorcima svinja poreklom iz RS-BiH koja su bila uključena u filogenetsku analizu su pokazale visok stepen sličnosti sa nukleotidnim sekvencama soja Mantova izolovanog kod svinja u Italiji, zatim sojeva DE006-14 i DE222-13 izolovanih kod svinja u Nemačkoj kao i sa sojem Jvnan izolovanog kod svinja u Kini. Istovremeno, izolati PCV2 utvrđeni kod svinja u RS-BiH su bili delimično slični sa sojem NIV-C SRB virusa PCV2 izolovanim kod svinja u Srbiji. Nukleotidne sekvence dva izolata parvovirusa svinja uključenih u filogenetsku analizu su pokazale visok stepen sličnosti sa sojem Challenge izolovanim kod svinja u UK, sojem Kresse izolovanim kod svinja u SAD-u kao i sojevima 77 i LZ izolovanim kod svinja u Kini. 